\title{
An unusual case of hyperkalaemia in infancy: question
}

\author{
Mireille Formosa $\cdot$ Nicholas J. Webb $\cdot$ Mohan Shenoy
}

Received: 7 June 2010/Revised: 10 September 2010 / Accepted: 24 September 2010 / Published online: 6 November 2010

(C) IPNA 2010

A male infant presented with recurrent episodes of hyperkalaemia and acidosis since birth. He was born by normal vaginal delivery at term weighing $2.7 \mathrm{~kg}$ (9th centile) with a head circumference of $33 \mathrm{~cm}$ (9th centile) to a mother with a known history of alcohol abuse. There were no perinatal problems. Mother's antenatal ultrasound scan at 20 weeks' gestation did not identify any foetal abnormalities.

At 1 month of age, the boy was admitted to the local hospital with a week's history of "funny spells", where he had extensor posturing of his trunk and limbs and cried out. These lasted for 2-3 min at a time. There was no apparent relationship to feeding or passing bowel motions. On examination, the child was noted to be thriving, with a weight of $3.29 \mathrm{~kg}$ (2nd centile), a head circumference of $36 \mathrm{~cm}$ (9th centile) and a length of $52 \mathrm{~cm}$ (9th centile). Blood pressure was $78 / 52 \mathrm{mmHg}$. Clinical examination was unremarkable. He was not dehydrated on clinical assessment. The external genitalia appeared normal.

Initial blood investigations (performed by venipuncture) showed serum potassium $7 \mathrm{mmol} / \mathrm{l}$, sodium $135 \mathrm{mmol} / \mathrm{l}$, chloride $112 \mathrm{mmol} / \mathrm{l}$, bicarbonate $19 \mathrm{mmol} / \mathrm{l}$, urea $2.1 \mathrm{mmol} /$ 1 and creatinine $26 \mu \mathrm{mol} / \mathrm{l}$. The complete blood count showed normal haemoglobin, white blood cell and platelet values. Liver function tests were within normal limits. Calcium, phosphate and magnesium were within the normal range. Glucose was $4.2 \mathrm{mmol} / \mathrm{l}$. Serum ammonia, lactate and

The answer to this question can be found at http://dx.doi.org/10.1007/ s00467-010-1684-x.

M. Formosa $\cdot$ N. J. Webb $\cdot$ M. Shenoy $(\varangle)$

Department of Paediatric Nephrology,

Royal Manchester Children's Hospital,

Oxford Road,

Manchester M13 9WL, United Kingdom

e-mail: mohan.shenoy@cmft.nhs.uk creatinine kinase were normal. Capillary blood gas showed a mild metabolic acidosis with a base deficit of -5.2 .

A working diagnosis of sepsis was originally considered, and he was treated with antibiotics intravenously. A complete septic screen was negative. Cerebrospinal fluid (CSF) lactate, plasma and CSF amino acids; random cortisol; thyroid function tests; and 17hydroxyprogesterone were all within the normal range. Serum aldosterone was entirely normal for age at $454 \mathrm{pmol} / 1$ (normal 300-1,500 pmol/1). Plasma renin activity was low at $<0.2 \mathrm{nmol} / 1$ per hour (normal 1.1 $2.7 \mathrm{nmol} / \mathrm{l}$ per hour). Urinary potassium was $10 \mathrm{mmol} / \mathrm{l}$, urine osmolality $151 \mathrm{mmol} / \mathrm{l}$ and plasma osmolality $290 \mathrm{mmol} / \mathrm{l}$. Urinary screen for drugs and toxins was negative. An ultrasound scan of the renal tract demonstrated two normal kidneys with no evidence of hydronephrosis or hydroureter.

The child had a trial of sodium bicarbonate, fludrocortisone and calcium resonium at 2 months of age. However, these were not sufficient to correct the hyperkalaemia, which at this stage was associated with poor weight gain $(3.7 \mathrm{~kg}, 0.4$ th centile). He was then commenced on low-potassium-containing milk. This corrected the hyperkalaemia. He was discharged home with serum potassium $3.8 \mathrm{mmol} / \mathrm{l}$, sodium $139 \mathrm{mmol} / \mathrm{l}$, chloride $100 \mathrm{mmol} / \mathrm{l}$, urea $1.2 \mathrm{mmol} / \mathrm{l}$ and creatinine $18 \mu \mathrm{mol} / \mathrm{l}$.

\section{Questions}

1. What is the differential diagnosis of hyperkalaemia in this child?

2. What are the causes of end-organ resistance to aldosterone?

3. What is the most likely diagnosis? 